\title{
G scome \\ Green Solvent Improving Mechanical Disruption of Palm Kernel Oil Extraction
}

\section{Eko K. Sitepu}

Department of Chemistry, Faculty of Mathematics and Natural Sciences, Universitas Sumatera Utara, Medan 20155, Indonesia. Carbon Research Centre, Universitas Sumatera Utara, Medan 20155, Indonesia

\section{Andy Chandra}

Department of Chemistry, Faculty of Mathematics and Natural Sciences, Universitas Sumatera Utara, Medan 20155, Indonesia

\section{Emma F. Zaidar}

Department of Chemistry, Faculty of Mathematics and Natural Sciences, Universitas Sumatera Utara, Medan 20155, Indonesia

\section{Annur Vika}

Department of Chemistry, Faculty of Mathematics and Natural Sciences, Universitas Sumatera Utara, Medan 20155, Indonesia

\section{Firman Sebayang}

Department of Chemistry, Faculty of Mathematics and Natural Sciences, Universitas Sumatera Utara, Medan 20155, Indonesia. Carbon Research Centre, Universitas Sumatera Utara, Medan 20155, Indonesia

\section{Fera Roswita Dewi}

Research Center for Marine and Fisheries Product Processing and Biotechnology, Jakarta, 10260, Indonesia

\section{Justaman Karo-karo}

Balai Riset dan Standarisasi Industri, Kementerian Perindustrian, Medan 20214, Indonesia

Juliati Br Tarigan ( $\sim$ juliati@usu.ac.id)

Universitas Sumatera Utara https://orcid.org/0000-0001-5705-506X

\section{Research}

Keywords: Green solvents, ethyl acetate, extraction, palm kernel

Posted Date: December 1st, 2020

DOl: https://doi.org/10.21203/rs.3.rs-114470/v1

License: (c) (1) This work is licensed under a Creative Commons Attribution 4.0 International License. Read Full License 


\section{Abstract}

Even though the mechanical extraction process offers a simple and environmentally friendly process, the recovery of oil is relatively low. Thermal pre-treating the oilseed increases the oil yield but produces unwanted oil colour. A new method which combines grinding and extraction using green solvents was developed to extract palm kernel oil. The performance of six different green solvents such as water, ethanol, isopropyl alcohol, dimethyl carbonate, ethyl acetate, and d-limonene in extraction palm kernel oil was determined using a controllable blender extractor (CBE), new extraction equipment modified from a household blender appliance. Further, ethyl acetate, which produced the maximum oil yield, was used to study the effect of the operating parameters of the CBE. The oil yield of $34.2 \pm 0.02 \%$ was obtained in the extraction condition of the ratio of palm kernel to ethyl acetate of 1:7, rotational speed of $5000 \mathrm{rpm}$ and 10 minutes extraction time. Compared to other green extraction methods, the CBE-intensified palm kernel oil extraction could save $>70 \%$ energy consumption. In terms of extraction time, the CBE-intensified could extract palm kernel oil faster than existing extraction methods.

\section{Introduction}

Vegetable oil is currently produced either by solvent extraction or mechanical disruption of oil bearing seed (Zhao et al. 2020). Due to the simple process and high extraction yield with an acceptable scent, the solvent extraction particularly using hexane is industrially preferable (Potrich et al. 2020; Mwaurah et al. 2020). However, hexane is toxic and flammable, which raises health and safety concerns (de Jesus and Filho 2020). In addition, the solvent extraction method requires thermal conditions for evaporation and consumes an excessive volume of hexane (Nguyen et al. 2020; Halim et al. 2012). Therefore green extraction processes have been developed to accommodate those issues. Supercritical fluid which utilizes carbon dioxide or solvents particularly in its critical condition to disrupt seed cell walls releasing oil to the environment, and mechanical disruption i.e. screw press which applies a non-inherent force to the seeds are the common green extraction process (Drinić et al. 2020). Even though a high purity of oil yield is extracted using the supercritical extraction method, a special reactor that can hold a high pressure is required for successful extraction, which, together with operating costs such as electricity, a specialized operator and periodic maintenance, limits its industrial application (de Jesus and Filho 2020).

Mechanical processes offer a simple and environmentally friendly extraction method. This extraction method is preferred in rural areas, as it requires low cost investment and semi-trained persons to operate (Nde and Foncha 2020; Bhuiya et al. 2020). In addition the by-product contains no toxic organic residue and can be used directly for other purposes, particularly for animal feed uses (Dal Prá et al. 2018). However the oil yield obtained using this method is quite low and is preferably applied to oleaginous oil seed / biomass (Li et al. 2019; Dal Prá et al. 2018; Nde and Foncha 2020). Many researchers observed 10 - $20 \%$ of residual oil remains in various oleaginous seed after a mechanical continuous extraction process (Mwaurah et al. 2020; Savoire et al. 2013; Bhuiya et al. 2020). In addition, this method cannot be applied to microalgae biomass as the cell walls are too small and rigid (Suh et al. 2015). 
Modification of the mechanical extraction machine combined with heating had proved to increase the extraction efficiency (Savoire et al. 2013). Subroto et al. (2015) observed an increase of $28.6 \%$ oil recovery when increasing the temperature to $105^{\circ} \mathrm{C}$. However a darker oil colour is obtained due to denaturation of protein in the Jatropha kernel, lowering oil viscosity. It was found that pre-heating the oil seed can also decrease the residual oil (Savoire et al. 2013; Rombaut et al. 2015). Pre-treating palm fruit with microwave irradiation for $3 \mathrm{~min}$ increased the oil yield from $7 \%$ to $19 \%$. Even though oil recovery was increased with the increased irradiation time, black coloured oil was produced (Cheng et al. 2011).

Recently, as environmental and health risk concerns increase, the utilization of green solvent in vegetable oil extraction has developed (Rincón-Cervera et al. 2020; de Jesus et al. 2019; Castejón et al. 2018; Kumar et al. 2017; Castro-Puyana et al. 2017; de Jesus and Filho 2020). Green solvent was used combined with other cell wall disruption methods such as supercritical, pressurized liquid extraction, ultrasound, microwave, or maceration (Castejón et al. 2018; de Jesus and Filho 2020). The combination of mechanical press followed by the supercritical carbon dioxide process to extract the residual oil showed increasing extraction efficiency (Rahman et al. 2012; Dal Prá et al. 2018). Furthermore similar oil yields could be extracted from Echium plantagineum $L$ seed using pressurized ethanol running at $150^{\circ} \mathrm{C}$ for 10 min and the soxhlet-hexane extraction method conducted for 480 min (Castejón et al. 2018). In addition, some bioactive compounds were extracted using green solvent producing oil with good oxidation stability (Rincón-Cervera et al. 2020). However seed grinding processes are required to reduce seed size and to increase the contact surface area of the cell walls. In fact some oil detected sticks to the grinding machine, which reduces the recovery yield.

Therefore this study aims to simultaneously grind and extract palm kernel oil using green solvents as the extracting agent. The home appliance capsule blender design was adopted and was equipped with a controlled motor. The CBE has a maximum speed of $16,000 \mathrm{rpm}$ and 2 blades to chop up the seed. The oil yield, free fatty acid (FFA) content and lipid profile in form of monoglyceride (MG), diglyceride (DG) and triglyceride (TG) were the outcomes of the CBE intensified palm kernel oil extraction operated at ambient temperature and pressure. The achievements as solvent extractors of green solvents such as water, ethanol, isopropyl alcohol, ethyl acetate, dimethyl carbonate and d-limonene were evaluated. Further, the best performance solvent was used to study the effect of the ratio of palm kernel to solvent, reaction time and the $\mathrm{CBE}$ rotation speed. Finally the energy consumption of the CBE was calculated and compared with other extraction methods.

\section{Materials And Methods}

\subsection{Materials}

Palm kernel was collected from a local palm oil industry in Medan, Sumatera Utara - Indonesia and stored in a cold room before use. All green solvents used in this study were purchased from local chemical stores and were used without any treatment. 
The Soxhlet extraction method was used to extract palm kernel oil and the oil yield was used as a benchmark to calculate the extraction efficiency of the intensified CBE. The procedures for Soxhlet extraction followed the published method described in the previous studies (Tarigan et al. 2019; AlHamamre et al. 2012). About $20 \mathrm{~g}$ of grounded palm kernel placed in a thimble was connected in a Soxhlet apparatus and extracted using hexane under reflux condition for $30 \mathrm{~min}$. The oil yield was calculated after solvent evaporation and stored in a desiccator for analysis.

\subsection{The CBE intensified palm kernel oil extraction}

Six different green solvents such as water, ethanol, isopropyl alcohol, ethyl acetate, dimethyl carbonate and d-limonene were added to palm kernel with a ratio of 1:3 (w/v) in the CBE (Fig. 1.). The extraction was conducted for $10 \mathrm{~min}$ with a rotational speed of $5000 \mathrm{rpm}$ at ambient temperature and pressure. The performance of hexane, a non-polar organic solvent, was also studied as a comparison. The oils and solvents were separated from the palm kernel cake using centrifugation working at $8000 \mathrm{rpm}$ for 5 minutes. The green solvent was evaporated and the oils were stored in a desiccator until analysis. The acid value was determined using standard titration method following the ASTM D664 procedure. The extraction efficiency was calculated based on comparison of the CBE-intensified oil yield with soxhlet and screw press oil yield.

$$
\text { Yield }_{C B E}=\frac{W_{C B E}}{W_{\text {palm kernel }}}
$$

$$
\text { Extraction Efficiency }(\%)=\frac{\text { Yield }_{C B E}}{\text { Yield }_{\text {Soxhlet or screw press }}} \times 100 \%
$$

where $W_{C B E}$ is the weight of $C B E$-intensified oil extracted and $W_{\text {palm kernel }}$ is the weight of palm kernel used.

\subsection{Fatty acid profile and lipid content analysis}

The fatty acid profile and lipid content in form of MG, DG and TG were determined using a gas chromatograph spectrometer (GC Shimadzu type 2010) equipped with a capillary column with a length of $15 \mathrm{~mm}$ and ID $0.25 \mathrm{~mm}$ and a flame ionization detector. Helium was used as carrier gas with constant delivered flow of $30 \mathrm{~mL} / \mathrm{min}$. The temperature of the detector and injection port was set to $370^{\circ} \mathrm{C}$.

\subsection{Statistical analysis}

The data from all experiments are expressed as mean \pm SD and were subjected to one-way ANOVA and Tukey's post hoc test using Statistica 13.3 software. The significance level was set to $a=0.05$ and differences were considered to be significant at $\mathrm{P}<0.05$. 


\section{Results And Discussion}

The quantity of oil contained in palm kernel seed was measured using the Soxhlet extraction method with hexane as a solvent. The result was used as a divisor to determine the extraction efficiency of the CBE intensified palm kernel extraction using green solvent. The oil yield using the Soxhlet oil method was $39.53 \pm 2.2 \%$ with acid value of $1.06 \pm 0.2 \%$. This result is in agreement with previous studies (Costa et al. 2019; Tarigan et al. 2017). The lauric acid dominated the fatty acid profile at a concentration of $47 \%$ while the oleic acid (15.6\%) was the highest for unsaturated fatty acid. As mentioned, the residual oil remaining after screw press method is $10-20 \%$; therefore the middle number was used as a comparison to calculate extraction efficiency based on the screw press.

Table 1. Fatty acid composition of palm kernel oil

\begin{tabular}{|c|c|c|c|}
\hline \multicolumn{2}{|c|}{ Fatty Acid } & \multirow{2}{*}{$\begin{array}{l}\text { Concentration }(\mathrm{g} / 100 \mathrm{~g}) \\
0.06\end{array}$} & \multirow{2}{*}{$\begin{array}{l}\text { Percentage } \\
0.16\end{array}$} \\
\hline$C_{6: 0}$ & Caproic & & \\
\hline $\mathrm{C}_{8: 0}$ & Caprylic & 1.84 & 4.66 \\
\hline $\mathrm{C}_{10: 0}$ & Capric & 1.58 & 4.00 \\
\hline $\mathrm{C}_{12: 0}$ & Lauric & 18.58 & 47.01 \\
\hline $\mathrm{C}_{14: 0}$ & Myristic & 6.03 & 15.25 \\
\hline$C_{16: 0}$ & Palmitic & 3.30 & 8.35 \\
\hline $\mathrm{C}_{18: 0}$ & Stearic & 0.92 & 2.33 \\
\hline $\mathrm{C}_{20: 0}$ & Arachidic & 0.08 & 0.21 \\
\hline $\mathrm{C}_{18: 1}$ & Oleic & 6.16 & 15.58 \\
\hline $\mathrm{C}_{18: 2}$ & Linoleic & 0.97 & 2.46 \\
\hline \multicolumn{2}{|c|}{ Total fatty acids } & 39.53 & \\
\hline \multicolumn{2}{|c|}{ Saturated } & 32.40 & 81.96 \\
\hline \multicolumn{2}{|c|}{ Monounsaturated } & 6.16 & 15.58 \\
\hline \multicolumn{2}{|c|}{ Polyunsaturated } & 0.97 & 2.46 \\
\hline
\end{tabular}

\subsection{Effect of different extraction solvents}


Six green solvents such as water, ethanol, d-limonene, dimethyl carbonate, isopropyl alcohol and ethyl acetate were used as solvent extractors on CBE-intensified palm kernel oil extraction and the solvent with the highest extraction efficiency was selected to study the operational variable of the CBE. As comparison, hexane also used either as a solvent for traditional soxhlet extraction or CBE-intensified palm kernel oil extraction. The extraction condition conducted for this experiments were ratio of palm kernel : solvent of 1:3(w/v), extraction time of 10 minutes and $5000 \mathrm{rpm}$ rotational speed. Figure $2 \mathrm{~A}$ shows that all green solvents could extract oil from the palm kernel with an average oil yield of $26 \%$ except water, which could not extract the lipid out of the cell walls. It is interesting to note that hexane, which has similar polarity with lipid, only extracts $24 \%$ of palm kernel oil in CBE-intensified extraction method. This is probably because the extracted oil in the hexane at that volume ratio had reached its saturation point. Increasing the volume of hexane used showed significantly increased oil yield. In addition, only ethanol had oil yields less than hexane. The highest oil yield was obtained using ethyl acetate $(29.5 \pm 1 \%)$. This result is in agreement with Cascant et al. who concluded that ethyl acetate has the potential to replace environmentally hazardous hexane as extracting agent due to its ability to extract all classes of lipid (Cascant et al. 2017).

The average extraction efficiency based on the soxhlet method was quite low $(66 \%)$ while the screw press method's extraction efficiency was $84 \%$. Ethyl acetate as the best extracting agent in this study showed extraction efficiencies of $74.6 \pm 2.5 \%$ and $95.9 \pm 3.2 \%$ based on soxhlet and screw press, respectively. These results showed that the CBE-intensified palm kernel oil extraction using green solvents has lower performance than the soxhlet and screw press methods. However green solvent has the potential to improve the mechanical disruption method with further variations of the operational parameters of $\mathrm{CBE}$ using ethyl acetate.

The average concentration of MG, DG and TG extracted using CBE-intensified palm kernel oil was 4, 2.2 and $84.4 \mathrm{~mol} \%$, respectively (Fig. 3A). The highest concentrations of MG and DG were extracted using dlimonene of $9.9 \pm 0.6$ and $6.4 \pm 1 \mathrm{~mol} \%$, respectively, which are 2.5 and 7.4 times higher than the soxhlet method. Even though the oil yield extracted using ethanol was the lowest, the highest TG concentration of $87.9 \pm 1.1 \mathrm{~mol} \%$ occurred using this green solvent. Overall the TG extraction efficiency of $99 \%$ showed that all the green solvents used have similar performance with the soxhlet-hexane method on TG extraction process.

\subsection{Effect of rotational speed}

The rotational speed of $\mathrm{CBE}$ is one of the important factors that impact the oil yield. Normally in chemical reactors, increasing the agitation / rotational speed could increase the mixing intensity of reactants yielding high mass transfer and enhancing reaction rates (Mueanmas et al. 2019). Therefore in this study 6 different rotational speeds starting from 3000 to $8000 \mathrm{rpm}$ with increments of $1000 \mathrm{rpm}$ were investigated in extraction conditions of ratio of palm kernel to ethyl acetate of 1:3 $(\mathrm{w} / \mathrm{v})$ and extraction time of 10 minutes. As shown in Figure 2B the rotational speed of CBE did not affect the oil yield. The average oil yield of $27.8 \%$ was obtained, which is less than the soxhlet and screw press method. The 
analysis of the variance test indicated a significant effect of changing the rotational speed for CBEintensified extraction efficiency of both the soxhlet and the screw press method. The significant effect was mainly driven by rotational speed of 6000 and $8000 \mathrm{rpm}$ which yielded the lowest extraction efficiencies of $66.5 \pm 2.4 \%$ and $67.1 \pm 0.5 \%$, respectively for comparison with soxhlet method and $85.5 \pm$ $3.1 \%$ and $86.3 \pm 0.6 \%$ for extraction efficiency based on the screw press method. For all variables tested, the highest extraction efficiency was obtained under the extraction condition of $5000 \mathrm{rpm}$ rotational speed.

The average concentrations of MG, DG and TG $(3.86,0.79$ and $84.72 \mathrm{~mol} \%)$ extracted using the CBEintensified method were similar to the concentration extracted using the soxhlet method (Fig. 3B). However, for some rotational speeds the extraction efficiency of MG, DG and TG exceeded the concentration extracted using the soxhlet method. The highest extraction efficiencies of MG, DG and TG were 138,125 and $103 \%$, respectively observed at rotational speeds of 6000,3000 and $4000 \mathrm{rpm}$, respectively. An ANOVA one-way test detected the significant effect either for MG, DG or TG. A Tukey test post-hoc analysis established that the significant effect was driven by a high extraction of MG at the rotational speed of $6000 \mathrm{rpm}(5.5 \pm 0.6 \mathrm{~mol} \%)$ while, in contrast, the low extraction of DG at a rotational speeds of $6000-8000 \mathrm{rpm}(0.36 \pm 0.1-0.45 \pm 0.1 \mathrm{~mol} \%)$ causes the significant effect.

\subsection{Effect of extraction time}

It is noted that extraction time has a significant effect on oil yield (Nguyen et al. 2020). Furthermore regarding production cost, electric consumption and extraction / reaction time have the biggest impact, as prolonged extraction / reaction time could increase the electricity consumption of the reactor (Chia et al. 2018). Therefore finding the specific extraction time is necessary. In this present study the extraction time was determined as ranging from 5 to 30 minutes in the extraction condition of the ratio of palm kernel to ethyl acetate of $1: 3$ at a rotational speed of $5000 \mathrm{rpm}$ (Fig. 2C). The average oil yield of $28.3 \%$ obtained from this parameter ranged from $25.2 \pm 0.38 \%$ to $29.5 \pm 0.2 \%$. The average extraction efficiency of the soxhlet method was $71 \%$, and $92 \%$ of the screw press method. The highest extraction efficiencies were observed after 10 minutes extraction time with values of $74.6 \pm 2.5 \%$ and $95.9 \pm 3.2 \%$ of the soxhlet and screw press methods, respectively. Significant effects were observed for this parameter both for the extraction efficiencies based on soxhlet and the screw press methods. The further Tukey post-hoc test did not detect the main effect.

Extraction time had a significant effect on the extraction efficiency of MG, DG and TG (Fig. 3C). The extraction of MG was significantly highest at 10 minutes extraction time achieving extraction efficiency of $99.5 \%$ whilst a $122 \%$ extraction efficiency of DG was achieved in the same extraction time. In contrast, the TG was completely extracted in 5 minutes extraction time compared to TG concentration using soxhlet-hexane.

\subsection{Effect of ratio palm kernel to ethyl acetate}


The effects of the ratio of palm kernel to ethyl acetate on CBE-intensified oil yield and MG, DG and TG extraction were investigated at seven different ratios in extraction condition of $5000 \mathrm{rpm}$ rotational speed and 10 minutes extraction time. The average extraction efficiency based on the soxhlet method was $74 \%$ with the highest $(86.53 \pm 3.6 \%)$ achieved at a ratio of $1: 7$. In contrast, the extraction efficiency based on the screw press method exceeded $100 \%$ at a ratio of $1: 6$ and $1: 7$ achieved $108.7 \pm 1.3 \%$ and $111.2 \pm 4.6 \%$, respectively (Fig. 2D). This result shows that the CBE-intensified is superior in palm kernel oil extraction against the screw press method and in fact this was done in only 10 minutes extraction time, which is faster than the traditional soxhlet and mechanical press methods. The univariate test of significance for both the extraction efficiency based on soxhlet and the screw press methods showed significant effects. The post-hoc Tukey test further detected that the significant effect was mainly drive by all the parameters tested. The results are similar to previous results in studies which used thin film devices in fatty acid to fatty acid methyl ester conversion efficiency of microalgae Chloroparva pannonica and fungi Mucor plumbeus biomass with a ratio of biomass to methanol at 1:6 to 1:18 (Sitepu et al. 2018a; Sitepu et al. 2018b; Sitepu et al. 2019).

Significant effects were determined for MG, DT and TG in this study. However the Tukey test post-hoc did not detect the main effect. The average concentrations of MG and DG obtained were quite similar with the concentrations extracted using the soxhlet-hexane method whilst the average TG concentration exceeded the standard. The highest concentrations of MG and DG of $3.96 \pm 0.4$ and $1.06 \pm 0.02 \mathrm{~mol} \%$ were observed at a ratio $1: 3$ at, respectively and a concentration of $90.5 \pm 0.4 \mathrm{~mol} \%$ was obtained for TG at a ratio of 1:4 (Fig. 3D).

\subsection{Energy consumption comparisons}

Energy consumption of CBE-intensified palm kernel oil extraction was determined as kilowatt hour electricity consumption per kilogram palm kernel used (Table 2). As comparison, the traditional Soxhlethexane extraction method was conducted using a hotplate magnetic stirrer as the heating source. The data of palm kernel oil extraction using the screw press method was obtained from published research (Ezeoha 2020). Another green extraction method using a digestive drug mainly composed of a mixture of amylase and protease enzymes was also used. This method used a shaking incubator to facilitate the hydrolysis reaction of palm kernel cell walls generating palm kernel oils (unpublished result). Due to insufficient data on the extraction of palm kernel oil using a subcritical fluid, the published result on the extraction Jatropha oil was used, as the oil content in Jatropha curcas is in a range similar to palm kernel (Liu et al. 2014).

Table 2. Comparison of energy consumption of some extraction methods. 


\begin{tabular}{|c|c|c|c|c|}
\hline $\begin{array}{l}\text { Extraction } \\
\text { Method }\end{array}$ & Seed & Extraction Condition & $\begin{array}{l}\text { Energy } \\
\text { Consumption } \\
\left(\mathrm{kWh} \mathrm{Kg}^{-1}\right)\end{array}$ & Ref. \\
\hline $\begin{array}{l}\text { CBE green } \\
\text { solvent }\end{array}$ & $\begin{array}{l}\text { Palm } \\
\text { kernel }\end{array}$ & $\begin{array}{l}\text { Palm kernel } 20 \text { gram, ratio palm kernel : } \\
\text { ethyl acetate }(1: 7) \text {, rotational speed } 5000 \\
\text { rpm, extraction time } 10 \text { minutes, oil yield }= \\
34.2 \%\end{array}$ & 12.53 & This study \\
\hline $\begin{array}{l}\text { Screw } \\
\text { press }\end{array}$ & $\begin{array}{l}\text { Palm } \\
\text { kernel }\end{array}$ & $\begin{array}{l}\text { Fabricated palm kernel screw press, } \\
\text { capacity } 101.7 \mathrm{~kg} \mathrm{~h}^{-1} \text {, speed } 56 \mathrm{rpm} \text {, oil } \\
\text { yield }=39 \%\end{array}$ & 45 & $\begin{array}{l}\text { (Ezeoha } \\
2020)\end{array}$ \\
\hline $\begin{array}{l}\text { Subcritical } \\
\text { fluid }\end{array}$ & $\begin{array}{l}\text { Jatropha } \\
\text { curcas }\end{array}$ & $\begin{array}{l}\text { Jatropha seed }=2.4 \text { gram, ratio jatropha : } \\
\text { solvent }(1: 20) \text {, temperature } 90^{\circ} \mathrm{C} \text {, pressure } \\
0.5 \mathrm{MPa}, 15 \text { minutes extraction time, oil } \\
\text { yield }=40.3 \%\end{array}$ & 57.3 & $\begin{array}{l}\text { (Liu et al. } \\
2014 \text { ) }\end{array}$ \\
\hline Enzymatic & $\begin{array}{l}\text { Palm } \\
\text { kernel }\end{array}$ & $\begin{array}{l}\text { Palm kernel } 20 \text { gram, ratio palm kernel : } \\
\text { water }(1: 5) \text {, concentration of digestive } \\
\text { drug } 9 \%(\text { wt } / \mathrm{v}) \text {, } \mathrm{pH} 9 \text {, incubation time } 90 \\
\text { min and temperature } 45^{\circ} \mathrm{C} \text {, oil yield }= \\
38.3 \%\end{array}$ & 74.25 & $\begin{array}{l}\text { Unpublished } \\
\text { result }\end{array}$ \\
\hline $\begin{array}{l}\text { Soxhlet- } \\
\text { hexane }\end{array}$ & $\begin{array}{l}\text { Palm } \\
\text { kernel }\end{array}$ & $\begin{array}{l}\text { Palm kernel } 20 \text { gram, } 150 \mathrm{ml} \text { Hexane, } 30 \\
\text { minutes extraction time, oil yield }=39.5 \%\end{array}$ & 15 & This study \\
\hline
\end{tabular}

As shown in Table 2 the energy consumption of CBE-intensified palm kernel oil using a green solvent was determined based on the maximum oil yield obtained in the extraction condition. The CBE consumed 1.5 $\mathrm{kW}$ to operate in room temperature. Therefore the total energy required for processing $20 \mathrm{~g}$ of palm kernel at a rotational speed of $5000 \mathrm{rpm}$ for 10 minutes was $12.53 \mathrm{kWh} \mathrm{kg}^{-1}$, which is equal to $45.11 \mathrm{MJ} \mathrm{kg}^{-1}$ seed. The energy consumption of CBE-intensified palm kernel oil extraction was lower than for other extraction methods (Table 2). The CBE-intensified method provides an energy saving of $72,78,83$ and $16 \%$ compared to the screw press, subcritical fluid, enzymatic and soxhlet-hexane processes, respectively. In addition, the CBE-intensified process could be conducted in only 10 minutes which is 33,89 and $67 \%$ faster than subcritical fluid, enzymatic and soxhlet-hexane processes, respectively.

\section{Conclusion}

The CBE-intensified palm kernel oil extraction combines grinding and extraction processes into a single step with a green solvent acting as extracting agent to collect the oil at ambient temperature and pressure. The CBE-intensified process combined with ethyl acetate could improve traditional mechanical disruption palm kernel oil extractions with oil yield exceeding the screw press method. The CBEintensified is energy efficient, and could save $>70 \%$ energy compared to other green extraction processes and $16 \%$ compared to the conventional soxhlet method. In terms of time saving, the CBE-intensified process is faster than the other extraction methods that we compared. Furthermore, the rapid high 
extraction efficiency of CBE-intensified palm kernel oil using ethyl acetate as the extracting solvent opens the possibility of economically feasible palm kernel oil production.

\section{Abbreviations}

CBE Controllable blender extractor

FFA Free fatty acid

MG Monoglycerides

DG Diglycerides

TG Triglycerides

\section{Declarations}

Ethics approval and consent to participate: Not applicable

Consent for publication: Not applicable

Availability of data and materials: All data generated or analysed during this study are included in this published article and its supplementary information files.

Competing interests: The authors declare that they have no competing interests.

Funding: Universitas Sumatera Utara research grant no. 266/UN5.2.3.1/PPM/SPP-TALENTA USU/2020 date $28^{\text {th }}$ April 2020.

Authors contributions:

EKS conducting the research work and writing the manuscript, $A C$ and $A V$ assisted in experimentation, EFZ asissted in data analysis, FS and FRD asissted in results and discusion section, JK supported in data analysis and draft revision, and JBT assisted in finalisation and submission manuscript.

Acknowledgements: The authors wish to thank Universitas Sumatera Utara for research funding through Talenta.

\section{References}

1. Al-Hamamre Z, Foerster S, Hartmann F, Kröger M, Kaltschmitt M (2012) Oil extracted from spent coffee grounds as a renewable source for fatty acid methyl ester manufacturing. Fuel 96:70-76. doi:https://doi.org/10.1016/j.fuel.2012.01.023 
2. Bhuiya MMK, Rasul M, Khan M, Ashwath N, Mofijur M (2020) Comparison of oil extraction between screw press and solvent (n-hexane) extraction technique from beauty leaf (Calophyllum inophyllum L.) feedstock. Industrial Crops and Products 144:112024. doi:https://doi.org/10.1016/j.indcrop.2019.112024

3. Cascant MM, Breil C, Garrigues S, de la Guardia M, Fabiano-Tixier AS, Chemat F (2017) A green analytical chemistry approach for lipid extraction: computation methods in the selection of green solvents as alternative to hexane. Analytical and Bioanalytical Chemistry 409 (14):3527-3539. doi:10.1007/s00216-017-0323-9

4. Castejón N, Luna P, Señoráns FJ (2018) Alternative oil extraction methods from Echium plantagineum L. seeds using advanced techniques and green solvents. Food Chemistry 244:75-82. doi:https://doi.org/10.1016/j.foodchem.2017.10.014

5. Castro-Puyana M, Marina ML, Plaza M (2017) Water as green extraction solvent: Principles and reasons for its use. Current Opinion in Green and Sustainable Chemistry 5:31-36. doi:https://doi.org/10.1016/j.cogsc.2017.03.009

6. Cheng SF, Nor L M, Chuah CH (2011) Microwave pretreatment: A clean and dry method for palm oil production. Industrial Crops and Products 34 (1):967-971.

doi:https://doi.org/10.1016/j.indcrop.2011.03.002

7. Chia SR, Chew KW, Show PL, Yap YJ, Ong HC, Ling TC, Chang J-S (2018) Analysis of Economic and Environmental Aspects of Microalgae Biorefinery for Biofuels Production: A Review. Biotechnology Journal 13 (6):1700618. doi:doi:10.1002/biot.201700618

8. Costa WAd, Bezerra FWF, Oliveira MSd, Andrade EHdA, Santos APMd, Cunha VMB, Santos DCSd, Banna DADdS, Teixeira E, Carvalho Junior RNd (2019) Supercritical CO2 extraction and transesterification of the residual oil from industrial palm kernel cake with supercritical methanol. The Journal of Supercritical Fluids 147:179-187. doi:https://doi.org/10.1016/j.supflu.2018.10.012

9. Dal Prá V, Soares JF, Monego DL, Vendruscolo RG, Guimarães Freire DM, Alexandri M, Koutinas A, Wagner R, Mazutti MA, Da Rosa MB (2018) Comparison of Different Compressed Fluids for Residual Oil Extraction from Palm Kernel Cake. Waste and Biomass Valorization 9 (2):265-271. doi:10.1007/s12649-016-9778-8

10. de Jesus SS, Ferreira GF, Moreira LS, Wolf Maciel MR, Maciel Filho R (2019) Comparison of several methods for effective lipid extraction from wet microalgae using green solvents. Renewable Energy 143:130-141. doi:https://doi.org/10.1016/j.renene.2019.04.168

11. de Jesus SS, Filho RM (2020) Recent advances in lipid extraction using green solvents. Renewable and Sustainable Energy Reviews 133:110289. doi:https://doi.org/10.1016/j.rser.2020.110289

12. Drinić Z, Pljevljakušić D, Živković J, Bigović D, Šavikin K (2020) Microwave-assisted extraction of $O$. vulgare L. spp. hirtum essential oil: Comparison with conventional hydro-distillation. Food and Bioproducts Processing 120:158-165. doi:https://doi.org/10.1016/j.fbp.2020.01.011

13. Ezeoha SL (2020) Effects of some kernel factors on palm kernel oil extraction using a screw press. Agricultural Engineering International: CIGR Journal 22 (1):156-161 
14. Halim R, Danquah MK, Webley PA (2012) Extraction of oil from microalgae for biodiesel production: A review. Biotechnology Advances 30 (3):709-732. doi:http://dx.doi.org/10.1016/j.biotechadv.2012.01.001

15. Kumar SPJ, Prasad SR, Banerjee R, Agarwal DK, Kulkarni KS, Ramesh KV (2017) Green solvents and technologies for oil extraction from oilseeds. Chemistry Central Journal 11 (1):9. doi:10.1186/s13065-017-0238-8

16. Li P, Sakuragi K, Makino H (2019) Extraction techniques in sustainable biofuel production: A concise review. Fuel Processing Technology 193:295-303. doi:https://doi.org/10.1016/j.fuproc.2019.05.009

17. Liu J, Chen P, He J, Deng L, Wang L, Lei J, Rong L (2014) Extraction of oil from Jatropha curcas seeds by subcritical fluid extraction. Industrial Crops and Products 62:235-241. doi:https://doi.org/10.1016/j.indcrop.2014.08.039

18. Mueanmas C, Nikhom R, Petchkaew A, lewkittayakorn J, Prasertsit K (2019) Extraction and esterification of waste coffee grounds oil as non-edible feedstock for biodiesel production. Renewable Energy 133:1414-1425. doi:https://doi.org/10.1016/j.renene.2018.08.102

19. Mwaurah PW, Kumar S, Kumar N, Attkan AK, Panghal A, Singh VK, Garg MK (2020) Novel oil extraction technologies: Process conditions, quality parameters, and optimization. Comprehensive Reviews in Food Science and Food Safety 19 (1):3-20. doi:10.1111/1541-4337.12507

20. Nde DB, Foncha AC (2020) Optimization Methods for the Extraction of Vegetable Oils: A Review. Processes 8 (2):209

21. Nguyen HC, Vuong DP, Nguyen NTT, Nguyen NP, Su C-H, Wang F-M, Juan H-Y (2020) Aqueous enzymatic extraction of polyunsaturated fatty acid-rich sacha inchi (Plukenetia volubilis L.) seed oil: An eco-friendly approach. LWT 133:109992. doi:https://doi.org/10.1016/j.Iwt.2020.109992

22. Potrich E, Miyoshi SC, Machado PFS, Furlan FF, Ribeiro MPA, Tardioli PW, Giordano RLC, Cruz AJG, Giordano RC (2020) Replacing hexane by ethanol for soybean oil extraction: Modeling, simulation, and techno-economic-environmental analysis. Journal of Cleaner Production 244:118660. doi:https://doi.org/10.1016/j.jclepro.2019.118660

23. Rahman NNA, Al-Rawi SS, Ibrahim AH, Ben Nama MM, Ab Kadir MO (2012) Supercritical carbon dioxide extraction of the residual oil from palm kernel cake. Journal of Food Engineering 108 (1):166170. doi:https://doi.org/10.1016/j.jfoodeng.2011.06.033

24. Rincón-Cervera MÁ, Galleguillos-Fernández R, González-Barriga V, Valenzuela R, Speisky H, Fuentes $J$, Valenzuela A (2020) Fatty Acid Profile and Bioactive Compound Extraction in Purple Viper's Bugloss Seed Oil Extracted with Green Solvents. J Amer Oil Chem Soc n/a (n/a). doi:10.1002/aocs.12328

25. Rombaut N, Savoire R, Thomasset B, Castello J, Van Hecke E, Lanoisellé J-L (2015) Optimization of oil yield and oil total phenolic content during grape seed cold screw pressing. Industrial Crops and Products 63:26-33. doi:https://doi.org/10.1016/j.indcrop.2014.10.001

26. Savoire R, Lanoisellé J-L, Vorobiev E (2013) Mechanical Continuous Oil Expression from Oilseeds: A Review. Food and Bioprocess Technology 6 (1):1-16. doi:10.1007/s11947-012-0947-x 
27. Sitepu EK, Corbin K, Luo X, Pye SJ, Tang Y, Leterme SC, Heimann K, Raston CL, Zhang W (2018a) Vortex fluidic mediated direct transesterification of wet microalgae biomass to biodiesel. Bioresource Technology 266:488-497. doi:https://doi.org/10.1016/j.biortech.2018.06.103

28. Sitepu EK, Jones DB, Tang Y, Leterme SC, Heimann K, Zhang W, Raston CL (2018b) Continuous flow biodiesel production from wet microalgae using a hybrid thin film microfluidic platform. Chemical Communications 54:12085 - 12088 doi:10.1039/C8CC07610C

29. Sitepu EK, Jones DB, Zhang Z, Tang Y, Leterme SC, Heimann K, Raston CL, Zhang W (2019) Turbo thin film continuous flow production of biodiesel from fungal biomass. Bioresource Technology 273:431-438. doi:https://doi.org/10.1016/j.biortech.2018.11.015

30. Subroto E, Manurung R, Heeres HJ, Broekhuis AA (2015) Mechanical extraction of oil from Jatropha curcas L. kernel: Effect of processing parameters. Industrial Crops and Products 63:303-310. doi:https://doi.org/10.1016/j.indcrop.2014.06.018

31. Suh WI, Mishra SK, Kim T-H, Farooq W, Moon M, Shrivastav A, Park MS, Yang J-W (2015) Direct transesterification of wet microalgal biomass for preparation of biodiesel. Algal Research 12:405411. doi:http://dx.doi.org/10.1016/j.algal.2015.10.006

32. Tarigan JB, Ginting M, Mubarokah SN, Sebayang F, Karo-karo J, Nguyen TT, Ginting J, Sitepu EK (2019) Direct biodiesel production from wet spent coffee grounds. RSC Advances 9 (60):3510935116. doi:10.1039/C9RA08038D

33. Tarigan JB, Prakoso HT, Siahaan D, Kaban J (2017) Rapid Biodiesel Production From Palm Kernel Through In Situ Transesterification Reaction Using $\mathrm{CaO}$ as Catalyst. International Journal of Applied Chemistry 13 (3):631-646

34. Zhao Q, Li P, Wang M, Zhang W, Zhao W, Yang R (2020) Fate of phospholipids during aqueous extraction processing of peanut and effect of demulsification treatments on oil-phosphorus-content. Food Chemistry 331:127367. doi:https://doi.org/10.1016/j.foodchem.2020.127367

\section{Figures}




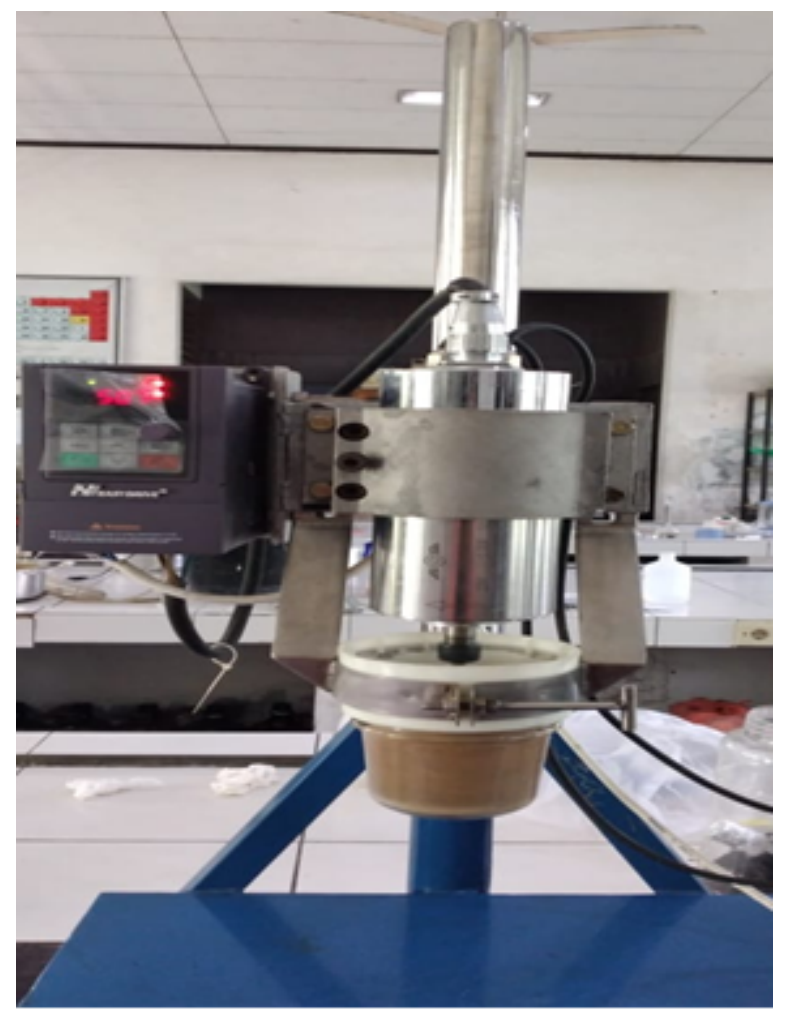

Figure 1

Photographic image of $\mathrm{CBE}$

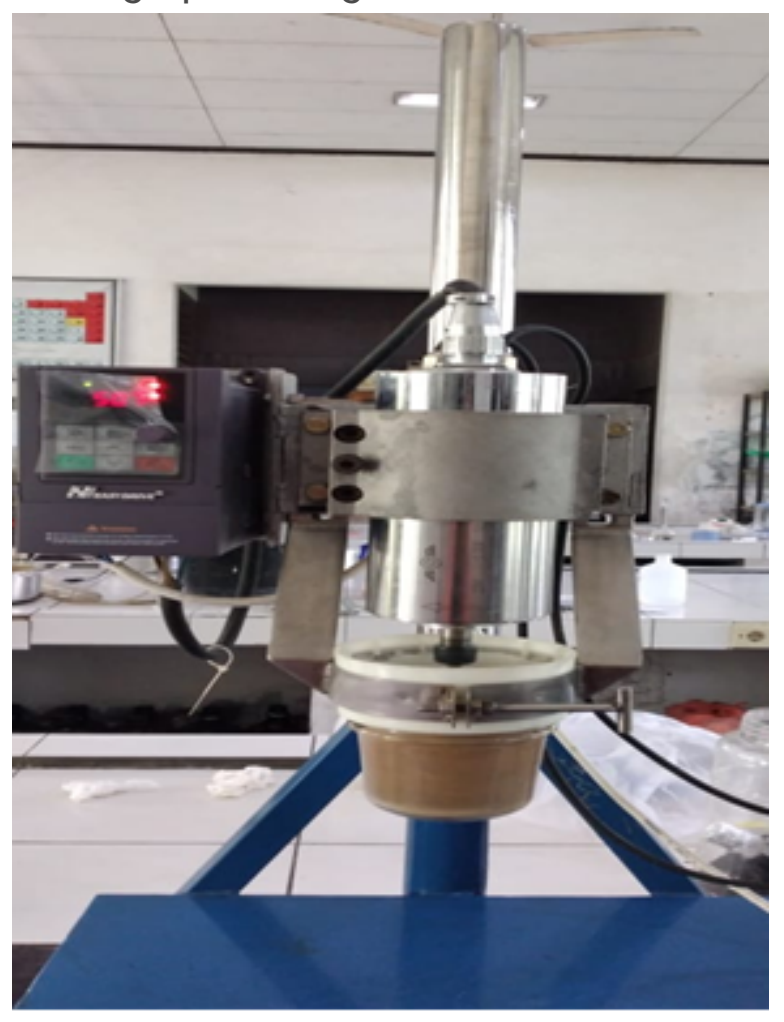

Figure 1

Photographic image of CBE 


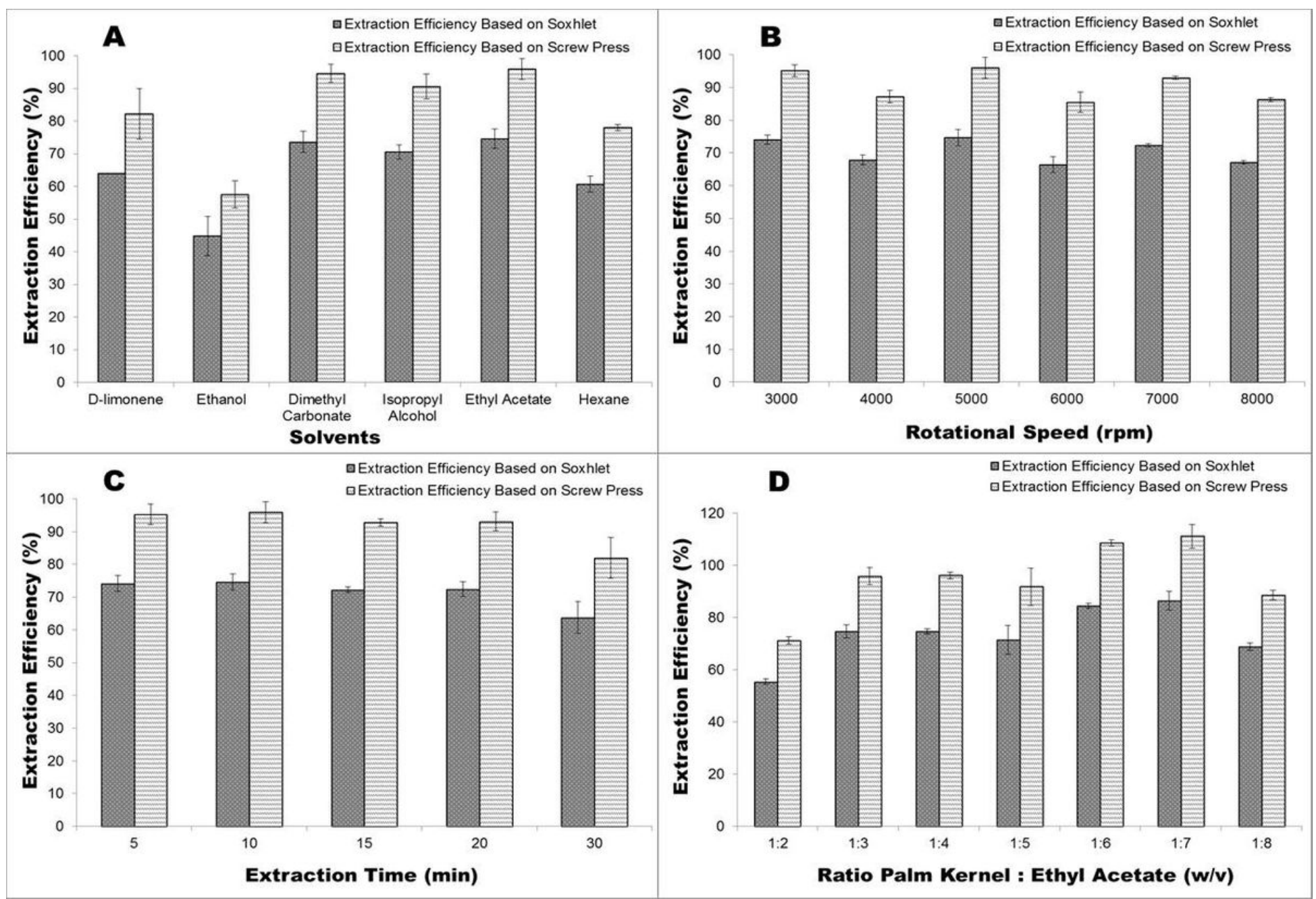

Figure 2

The effect of solvents type (A); rotational speed (B); extraction time (C) and ratio palm kernel to ethyl acetate (D) on extraction efficiency based on the soxhlet and screw press methods of CBE-intensified palm kernel oil extraction. 


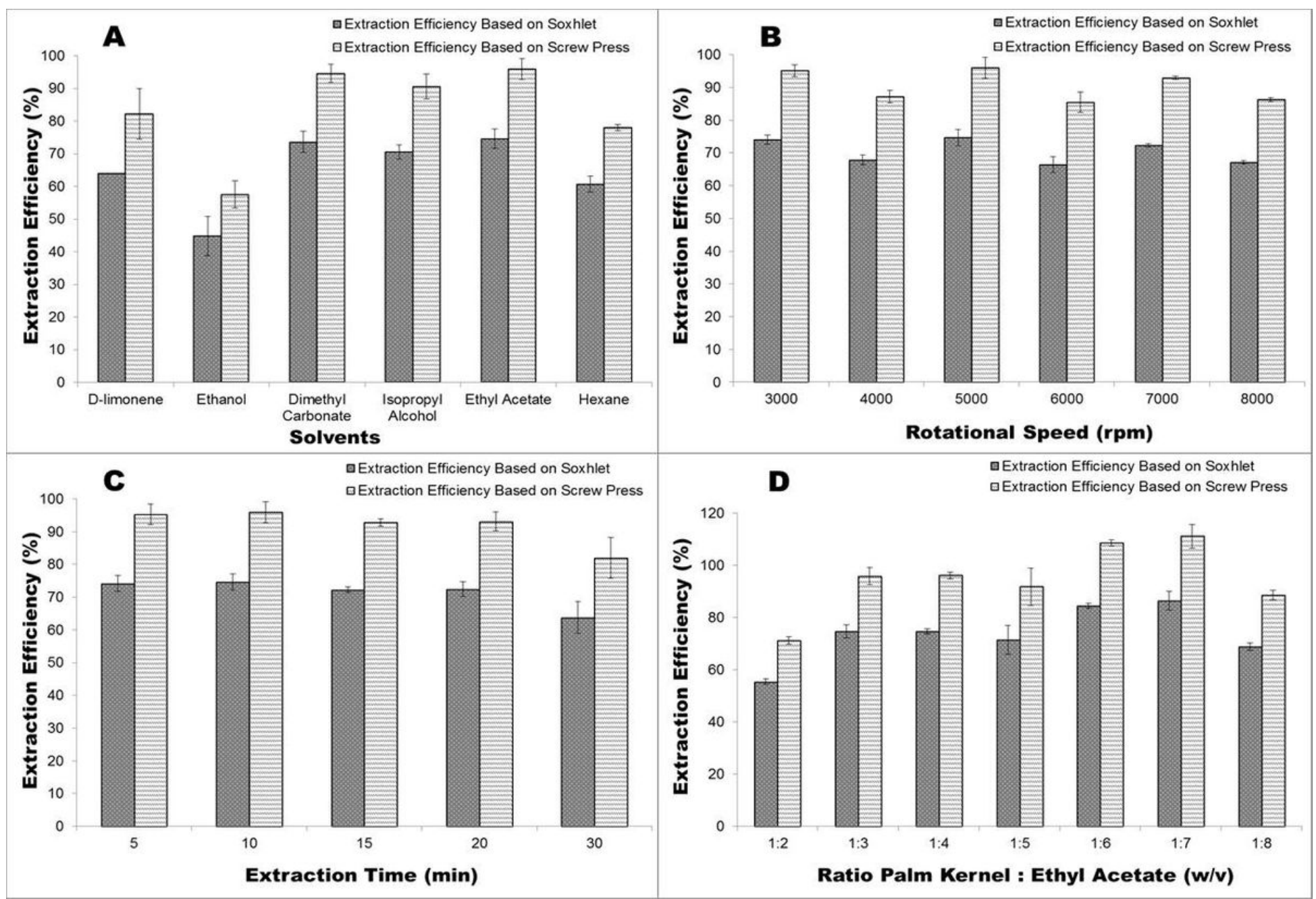

Figure 2

The effect of solvents type (A); rotational speed (B); extraction time (C) and ratio palm kernel to ethyl acetate (D) on extraction efficiency based on the soxhlet and screw press methods of CBE-intensified palm kernel oil extraction. 


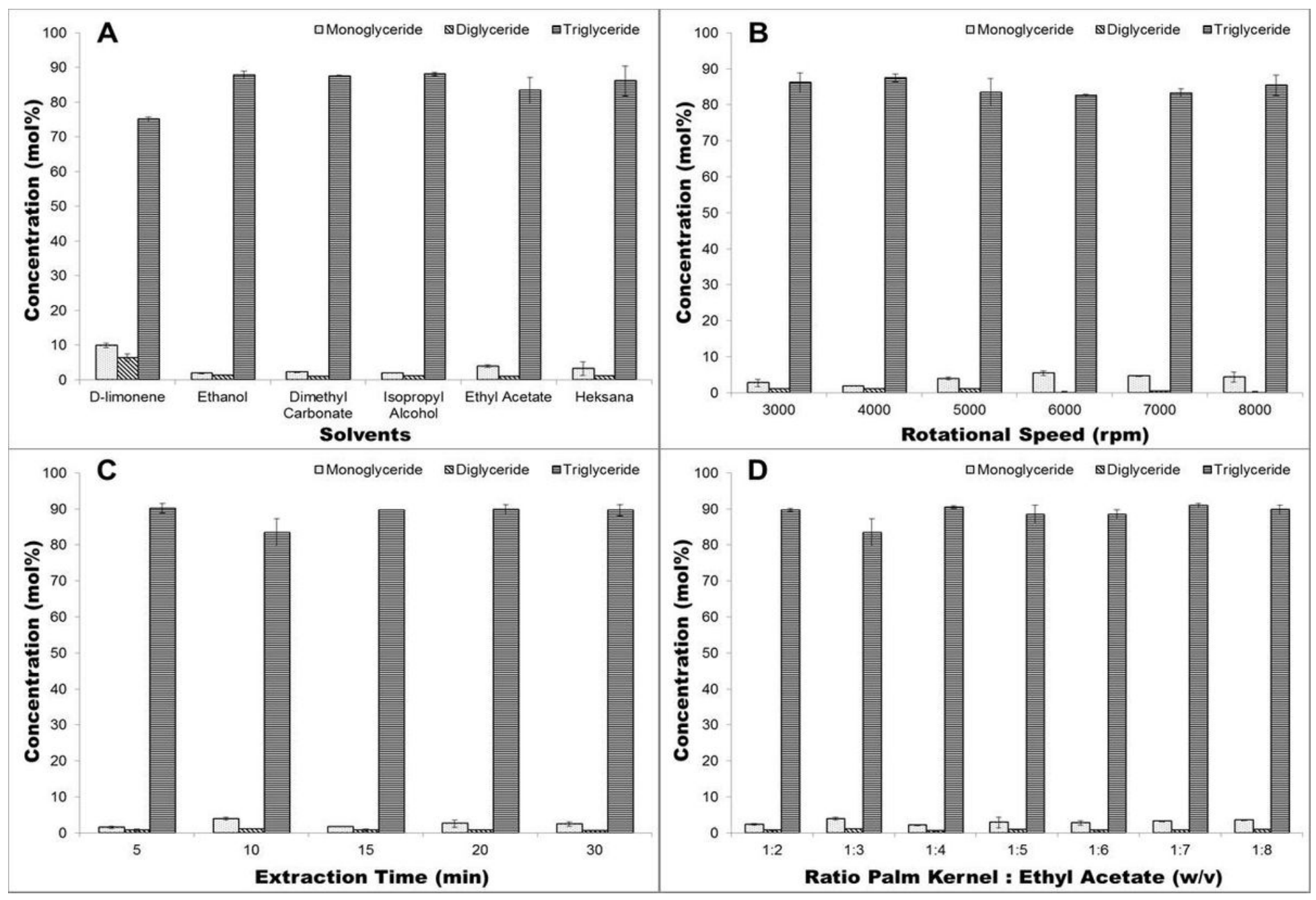

Figure 3

The effect of solvents type (A); rotational speed (B); extraction time (C) and ratio palm kernel to ethyl acetate (D) on concentration of MG, DG and TG extracted using CBE. 


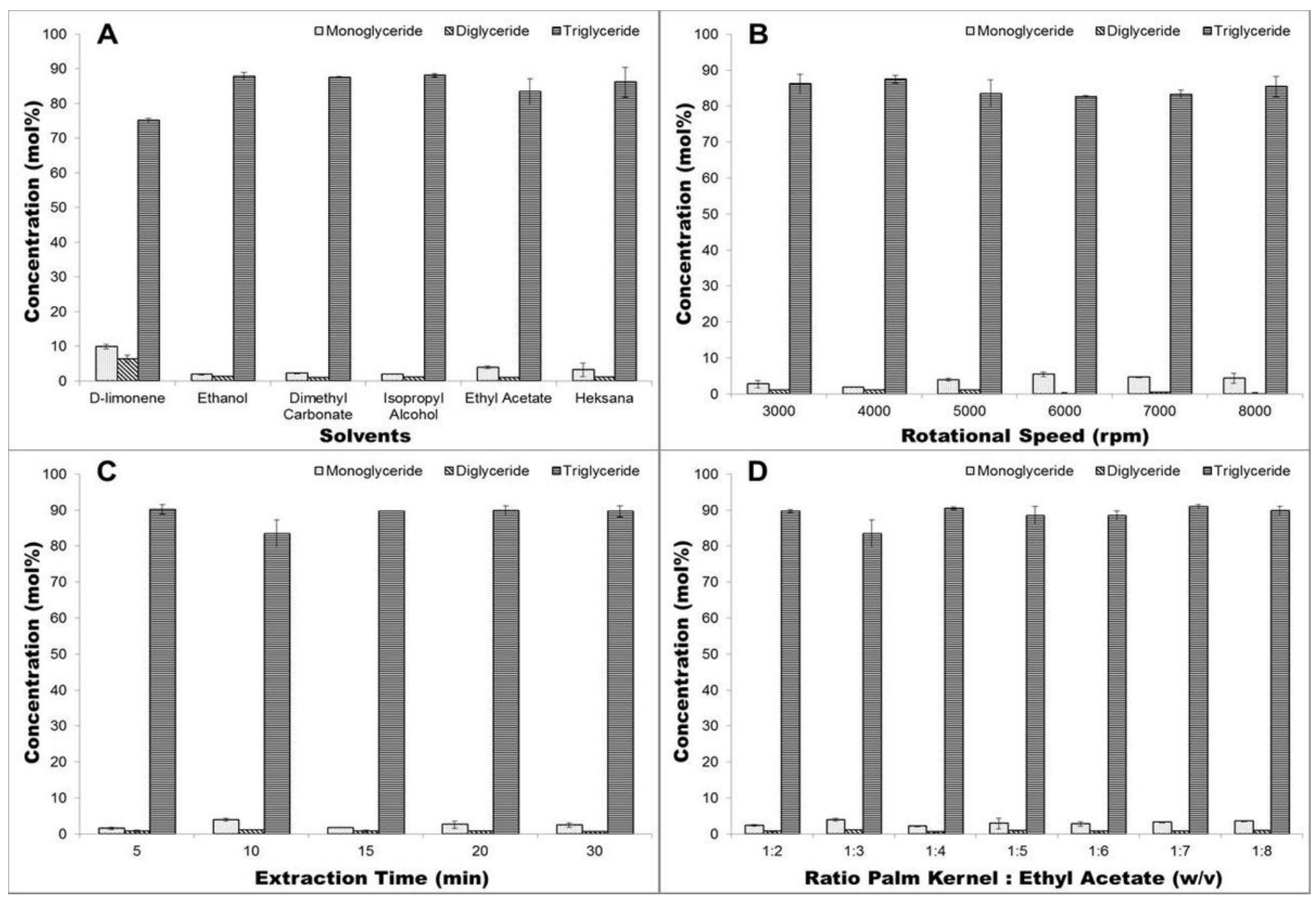

Figure 3

The effect of solvents type (A); rotational speed (B); extraction time (C) and ratio palm kernel to ethyl acetate (D) on concentration of MG, DG and TG extracted using CBE.

\section{Supplementary Files}

This is a list of supplementary files associated with this preprint. Click to download.

- Graphicalabstract.jpg

- Graphicalabstract.jpg

- SupplementaryInformationv1.docx

- SupplementaryInformationv1.docx 